International Journal of Linguistics, Literature and Culture
Available online at https://sloap.org/journals/index.php/ijllc/
Vol. 5, No. 6, November 2019, pages: 102 107
ISSN: 2455-8028
https://doi.org/10.21744/ijllc.v5n6.793

\title{
Deconstruction of the Colonial Discourse on the Erpangir Ku Lau Ritual in Karo Society
}

Vanesia Amelia Sebayang a

Article history:

Received: 09 May 2019

Accepted: 30 September 2019

Published: 07 November 2019

\section{Keywords:}

colonialism;

deconstruction;

erpangir ku lau;

karo society;

ritual;

\begin{abstract}
Erpangir ku lau is a ritual of cleansing based on Hindu Pemena teachings. This ritual teaches the Karo people to maintain harmonious relations between humans, the forces of nature, and the Creator. However, in the Dutch colonial era, erpangir lau was stopped because it was part of the worship and the practice of magic. The method used in this article is a descriptive qualitative research method that uses theory as a basis. This qualitative descriptive design format embraces phenomenology and post-positivism. This study aims to describe, summarize the various situations or phenomena of social reality in a society that are the object of research, and try to pull that reality to the surface as a description of certain conditions, situations, or phenomena. The findings obtained are that the colonial influence still imprinted on the person of the Karo people even though the occupation had long since ended. Concerning the Dutch colonial discourse, it is necessary to carry out a deconstruction practice to reverse the Karo people's perspective on the erpangir ku lau rites. The diversity of spiritual practices is proof that every nation in the world has its unique way based on its understanding of the world system. The deconstruction of the Dutch colonial discourse over the erpangir ku lau was carried out to create a sense of mutual understanding and to revive Karo community relations.
\end{abstract}

2455-8028 ${ }^{\circledR}$ Copyright 2019. The Author. This is an open-access article under the CC BY-SA license (https://creativecommons.org/licenses/by-sa/4.0/) All rights reserved.

\footnotetext{
Author correspondence:

Vanesia Amelia Sebayang,

Fakultas Ilmu Budaya, Universitas Sumatera Utara, Indonesia.

Email address: vanesia.amelia@usu.ac.id
}

\section{Introduction}

Colonial is different from imperial. It was revived with a colonial process. The outputs are then sent back to their home countries as the British did for example India. Colonial events related to the economic growth of European countries in the 19th century so they need a new territory related to the system of control and regulation based on the strength of the European nation (Mullaney, 2010).

${ }^{a}$ Universitas Sumatera Utara, Indonesia 
priests anchored in East Sumatra (now North Sumatra). Led by Rev. Hendrik C. Kruyt and Nicolas Pontoh, the NZG delegates then began their mission marked by the construction of the First Protestant Church in Buluhawar, Sibolangit. According to an interview with Eka (September 2018), the Church is no longer actively used as a place of worship but as a literacy museum as well as the Gospel Preaching Zending Museum which is managed by Saluran Berkat Funds.

But on its way, the sending carried out by the Dutch was full of violence and coercion. The Netherlands intervened in the noble beliefs of the Karo people, starting from changing the Hindu name Pemena to Perbegu, limiting the implementation of religious rituals, to changing the Karo people's concept of Dibata (God) and the universe. Dibata is described as something abstract and has a negative connotation. Pemena Hinduism was subsequently considered a religion of worshiping black magic and magic.

After successfully occupying Tanah Karo, the Dutch divided the Karo tribe by using the politics of devide et impera. To support its divided politics, the Dutch also began to demarcate the territories of the Karo tribe and seat tribal leaders and customary elders based on their wishes (Putro, 1979). The Dutch Colonial created a tragic reality of colonialism, that the oppression of the sons and daughters of the earth was carried out through the use of 'weapons' of indigenous people who were co-opted and 'bought' by the rulers of the colonial government. This is the form of political devide et impera in its naked and visible form. The politics of devide et impera had an impact on the land of the Dutch East Indies government which experienced a peak of economic growth, underwent a process of modernization and underwent a process of transformation and then moved its colonial society to abandon traditional agrarian culture towards modern urban culture (Susanto, 2003).

Dutch has the conception that the Karo tribe must be divided so that the integrity of the Five Merga or Merga Silima cultural patterns that exist in their socio-cultural system can be ransacked until destroyed and replaced with new cultural patterns which are certainly following the outlook of the colonized nation's life. The Karo code of conduct that reflects his honest personality, mutual respect, and anti-all forms of colonialism, according to the Dutch government, must be revised in every way and tactic so that the Karo people can at least become a docile nation towards the Dutch colonialism which is marked by the zending politics started by the NZG's zending politics on 1890 in Sibolangit.

Therefore, deconstructive studies are needed to expose the injustice and marginalization of the colonizing nation against its colonies. According to the theory of the discourse of the power of knowledge by Foucault, the researcher explained that the construction of the Dutch colonial discourse towards the Karo community was also a form of the relation of the Knowledge Power discourse. Power, in this case, is interpreted as oppression, restriction, the power of creating a new reality, to the power of creating a domain of objects and truth. Without knowledge, power is not possible, but knowledge is not possible without giving birth to power. The power relationship extends complexly to every aspect of our social, cultural and political life and maintains this relationship not only with threats but with the internalization of norms/values that apply in the social order (Sarup, 1993).

\section{Materials and Methods}

The method used in this article is a descriptive qualitative research method that uses theory as a basis. This qualitative descriptive design format embraces phenomenology and postpositivism. This study aims to describe, summarize the various situations or phenomena of social reality in a society that are the object of research, and try to pull that reality to the surface as a description of certain conditions, situations, or phenomena.

Following the explanation of Sardar \& van Loon (2001), culture has replaced the community in Cultural Studies. The community referred to in this study is a village, one or several sub-districts, several municipalities, and so on, it can even be a country or a region. The pros and cons of the Karo community related to erpangir ku lau used to make the community as the subject of his research (Bungin, 2007; Yasa et al., 2017).

\section{Results and Discussions}

The colonial construction created by the Dutch is still inherited to this day and has an impact on the changing attitude of the Karo people in understanding the concepts of Dibata, bègu jabu (ancestors), and the supernatural powers guarding the universe today. They also no longer understand the concept of segara gunung (sacred), so there is a lack

Sebayang, V. A. (2019). Deconstruction of the colonial discourse on the erpangir ku lau ritual in karo society. International Journal of Linguistics, Literature and Culture, 5(6), 102-107. https://doi.org/10.21744/ijllc.v5n6.793 
of respect for the supernatural forces of the inhabitants of the universe. This is evident from the destruction of nature and the level of saturation of soils in agricultural areas due to the use of massive chemicals.

According to Cardinal, the colonial influence remained imprinted in the person of the colonized nation during the colonial era itself which had long since ended. The current condition of the Karo people is by the Cardinal's opinion and the opinion regarding these conditions: The influence of Dutch colonialism in Tanah Karo in the past has caused historical trauma that is still ongoing in today's society. This growing historical trauma affects the economic position, religion is reversed, cultural dysfunctional, to the impact on the verification of the cultural identity of the Karo people. As stated by Jeff Contassle (Cardinal, 2017) follows:

"Colonialism has disrupted our relationships with the natural world and estimates 5000-8000 indigenous nations around the world trapped within 77 different countries as peoples for the state to 'manage'.

In addition to the impact on the destruction of nature and the environment in which they live, the loss of understanding of the harmonization of the three worlds (creator, fellow human, and nature) results in social pathology (social disorders) in the Karo community today known as ACC (anceng, cian, cekurak). Anceng means happy to see other people being difficult, hard to see others happy); cian means jealousy/envy; and cekurak which means happy talking about the ugliness of others which is then abbreviated to ACC.

The noble values of the ancestors inherited in erpangir ku lau rites in the past have actually formed the sublime identity of the Karo people namely 3M2P (mehamat, metami, melias, perkuah, and perkeleng) which means always polite (mehamat), persuasive (metami), full of love (melias), generous (perkuah), and merciful (perkeleng). As he forgot about carrying out this ritual, the noble identity of the ancestors also disappeared in the minds and understanding of the Karo people. The Karo community has changed from a polite person who respects the three layers of the world to a Karo community with a person who is rude, selfish, filled with suspicion between people, and has no respect (interview with Basmi Tarigan, July $14^{\text {th }}, 2019$ ).

Sharp says that colonialism and orientalism is a form of representation produced by various discourses (Sharp, 2013):

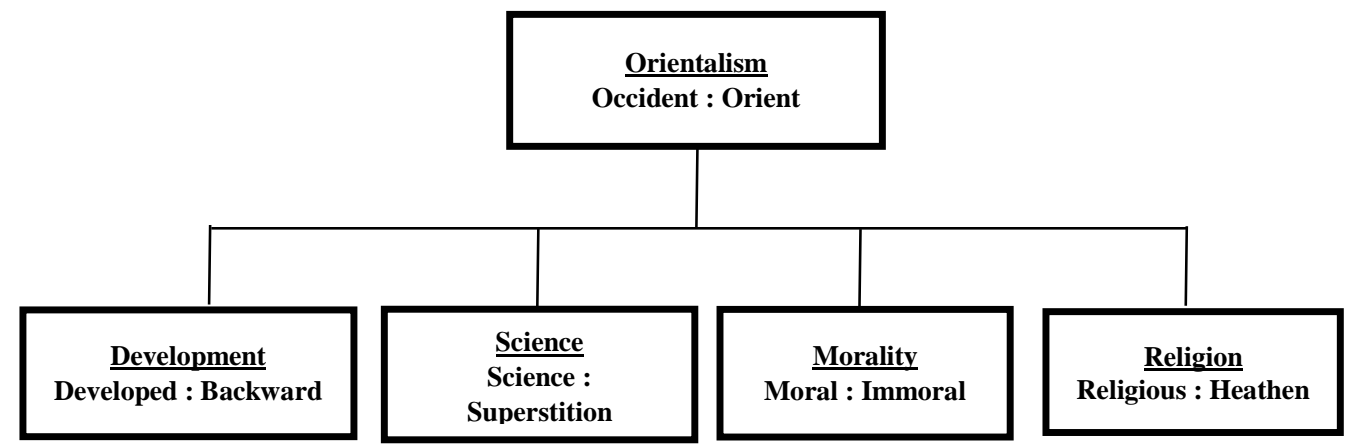

It is not possible to understand the behavior of other groups if we analyze them in terms of our motives, habits, and values; instead, an interpretation must be made from the point of motives, habits, and values known as cultural relativism (Horton, 1999a). The next step is recognition of our position (self-location) as well as a critical first step in the practice of decolonization (Horton, 1999b). This is done to show respect for our ancestors and to allow the community to find us. Once we self-locate, we can determine what our role will be and how we will participate in the practice of decolonization (Cardinal, 2017; Kawangung, 2019)

Furthermore, deconstruction is interpreted as an attempt to reverse the binary opposition that Karo Pemena is a worshiper of black magic and Christianity is an ideal religion. For the Karo Hindu Pemena community, communication and the interconnectedness of the three worlds is the core of life that forms a genuine identity. In the end, spiritual practice becomes the media that perpetuates this identity. These spiritual practices bring representatives from all three worlds into space and carry out their respective functions. As said by Cardinal as follows (Cardinal, 2017):

Connection to the spirit and spiritual practices are so important to understanding indigenous identities. each indigenous nation has its own natural laws and spiritual practices that cannot be understood without being lived. 
Understanding the sacredness of the three worlds and the elements in them today is no longer interpreted the same as before. In fact, in society, the violence of colonial influence did not only occur in religious institutions but also in educational institutions. Indonesia's young generation, in general, is currently being influenced by formal education in official government institutions based on Western perspectives. This European-style education unconsciously helped perpetuate the power of Western epistemology in understanding the values of knowledge (indigenous knowledge). The younger generation is being driven further and further away from the noble values of the ancestors and replaced by a modern Western education that further glorifies nationality. Batiste also explains the following (Cardinal, 2017):

“...colonized education as using eurocentric curricula, rooted in the colonial history of education, and perpetuated by cognitive manipulation used to disclaim other knowledge bases and values. on eurocentrism in schools, schools perpetuated damaging myths about Indigenous knowledge and heritage, language, beliefs, and ways of life. it also established eurocentric science as the dominant mode of thought".

According to Smart in understanding the ideology and beliefs of the nations of the world, three steps are required. First, there are vital elements in various kinds of stories about human experiences in life including the beliefs and noble ideas of ancestors. The ancestral beliefs and ideas later became the greatest legacy in human civilization. Second, and more important is the fact that today is to understand the meaning and cultural values of the past at present, we first need to understand why the worldview overrides them ${ }^{[11]}$. In this case, to understand erpangir ku lau, we must first understand the people of Karo Pemena. Third, we as individuals may try to form a picture of our reality that is full of emotions but this is always related to our views of extraordinary ideas that come from different cultures and civilizations. In closing, Smart understands the cultures possessed by each individual or group in this world have contributed greatly to shaping human civilization, therefore the religion and ideology contained therein cannot be ignored.

It should be noted that in the journey to understand world religions, it is not justified to define religion with too narrow a meaning. Us academics need to study secular ideology as part of the story of the human perspective. According to Smart, the separation between ancestral beliefs or religions with new religions is considered to be a silly act of man. Ancestral beliefs or religions sometimes have the same function as new religions in the social system of society, moreover, human values contained in ancestral beliefs or religions do not appear to be reflected in the religions introduced by modern-day Western nations (Smart, 1989).

To understand their religious views and ancestral beliefs and ritual practices, we need an imagination. We must enter the life of a society that considers that the religion or belief of the ancestors is sacred and meaningful. As the Indian proverb says: "Never judge a person until you have walked a mile in his moccains". Smart said he disagreed with Christian theologians by saying:

"Once a Christian theologian complained to me in a public discussion because I had dealt among others themes with Buddhist attitudes to creation: "What need to do we have to consider Buddhism, since it is incompatible with the Gospel, and the Christian Gospel is all the truth we need?" It seems too inappropriate to be so defensive, and a limitation on this man's knowledge of the forces animating different parts of humanity. Anyway, I craftily replied: "You must indeed have read a lot, to know Buddhism is incompatible with the Christian Gospel."

Smart helps us change our perspective in understanding the spirituality practices of the tribes in the world. The diversity of spiritual practices is proof that they have their unique ways based on their understanding of the world system. According to him, our perspective must be reversed with the perspective that we have obtained as a colonial legacy. Smart also believes that pluralism will be richer because of the existence of this noble and extraordinary traditional religion and religion. This is an additional reason why it is important for us to know something about other people, even if there is a group that disagrees, but if it is implemented it will create a sense of mutual understanding and can revive community relations (Smart, 1989).

Hinduism embodied in the Karo Pemena religion, is felt to be a very imprint in its struggle against colonial violence against the Karo people, and how ultimately this small-scale religion must submit to the winds of change determined by the West. However, today there are Karo people with deep spiritual concern and do not want to ally with any formal religious movement, and see the highest spiritual meaning about nature and fellow human beings. They ended up volunteering to re-embrace the Pemena religion, and for the Karo people who stick to their beliefs, they respect their roots, but they try to adapt. Therefore, we must begin to appreciate the local conditions of the community following the postcolonial mandate, to accommodate people who write their history (Susanto, 2003).

Sebayang, V. A. (2019). Deconstruction of the colonial discourse on the erpangir ku lau ritual in karo society. International Journal of Linguistics, Literature and Culture, 5(6), 102-107. https://doi.org/10.21744/ijllc.v5n6.793 
After discussing prayers and musical instruments used in erpangir $k u$ lau, the following will explain the interrelationship of erpangir ku lau in the harmony of the three world systems of the Karo people. Erpangir ku lau consists of music, dance, offerings and prayers affected the harmonization of the three worlds in Karo cosmos system as pray and surrender to the Creator; to maintain water sources, and environmental cleanliness by using environmentally friendly materials; and live to socialize, pay attention to each other, and help with sangkep nggeluh (rakut sitelu and tutur siwaluh).

As a deconstruction result, here are the important roles of carrying out erpangir ku lau: (1) strengthen kinship and brotherhood with sangkep nggeluh; (2) all beings need to be cared for and fed; (3) environmentally friendly because they contain materials derived from nature; (4) substances contained in kaffir lime herbs help to clean bacteria in rivers and water sources; (5) the aroma of kaffir lime and other oranges provides a relaxing effect for mind therapy; and (6) the mixture of kaffir lime and other oranges helps cleanse the body without side effects such as chemicals in modern soaps.

\section{Conclusion}

Of course what has been explained above is in accordance with the mandate of Critical Theory of science which guarantees several points, namely: (1) science is not free of value because of the dynamic socio-cultural reality; (2) connecting the past, present, and future and supporting future progress with emancipatory social-political action; (3) holds that domination is structural in order to help individuals/communities understand the roots of the oppression they experience; (4) false human consciousness is perpetuated through domination, hegemony, and ideology and Critical Theory tries to uncover false consciousness and change it; (5) Critical Theory believes that change can be carried out starting from oneself, family, and so on; (6) study the dialectical relationship between structure and individuals; and (7) humans are responsible and obliged to prevent oppression between people (Lubis, 2006).

As a contemporary variant of Critical Theory, deconstruction and postcolonial studies are presently focusing their studies on the problems of injustice that occur in the socio-cultural and scientific fields, one of which is caused by colonialism and the epistemology narcissism of the modern era. Deconstruction as a contemporary cultural study also offers a critical understanding to uncover various imperialist dimensions found in socio-cultural science (Lubis, 2006).

\section{Conflict of interest statement}

The author declared that she has no competing interests.

Statement of authorship

The author has a responsibility for the conception and design of the study. The author has approved the final article.

Acknowledgments

The authors would like to thank the reviewer for their consideration of the further process of the present paper. Thanks to the editor of IJLLC for the valuable support, time as well as advice. 


\section{References}

Bungin, B. (2007). Penelitian kualitatif: komunikasi, ekonomi, kebijakan publik, dan ilmu sosial lainnya. Kencana.

Horton, P. (1999b). Sosiologi - Jilid 2 (terjemahan). Jakarta: PT Erlangga.

Horton, P. (1999a). Sosiologi - Jilid 1 (terjemahan). Jakarta: PT Erlangga.

Kawangung, Y. (2019). Religious moderation discourse in plurality of social harmony in Indonesia. International Journal of Social Sciences and Humanities, 3(1), 160-170. https://doi.org/10.29332/ijssh.v3n1.277

Lubis, A. Y. (2006). Dekonstruksi Epistemologi Modern. Jakarta: Pustaka Indonesia Satu.

Mullaney, J. (2010). Postcolonial literatures in context. A\&C Black.

Putro, B. (1979). Karo dari Zaman ke Zaman (Jilid I). Medan: Ulih Saber.

Sardar, Z., \& Van Loon, B. (2001). Mengenal cultural studies for beginners. Mizan.

Sarup, M. (1993). An introductory guide to post-structuralism and postmodernism. Pearson Education.

Sharp, J. P. (2013). Geopolitics at the margins? Reconsidering genealogies of critical geopolitics. Political Geography, 37, 20-29. https://doi.org/10.1016/j.polgeo.2013.04.006

Smart, N. (1998). The world's religions. Cambridge University Press.

Susanto, A. B. (2003). Identitas dan postkolonialitas di Indonesia. Kanisius.

Wright Cardinal, S. (2017). Beyond the sixties scoop: reclaiming indigenous identity, reconnection to place, and reframing understandings of being indigenous (Doctoral dissertation).

Yasa, I. N., Santoso, A., \& Roekhan, -. (2017). The resistance of slave in colonial era toward Surapati by Abdoel Moeis. International Journal of Linguistics, Literature and Culture, 3(1), 86-92.

\section{Biography of Author}

\begin{tabular}{|l||}
\hline \\
Vanesia Amelia Sebayang was born in Medan, November 20 ${ }^{\text {th }} 1988$. Worked as a \\
Universitas Sumatera Utara, Medan-Indonesia. Bachelor of Arts in Ethnomusicology, \\
Faculty of Cultural Studies, Universitas Sumatera Utara in 2011. Masters in Art Studies \\
from the Masters in Art Creation and Study, Faculty of Cultural Studies, Universitas \\
Sumatera Utara in 2013. Currently, took the doctoral programme in Postgraduate \\
Studies, Faculty of Arts, Udayana University, Denpasar-Bali. Besides working as a \\
lecturer, she is also active in cultural preservation organizations named Sumatra \\
Heritage Trust. \\
Email: vanesia.amelia@usu.ac.id
\end{tabular}

Sebayang, V. A. (2019). Deconstruction of the colonial discourse on the erpangir ku lau ritual in karo society. International Journal of Linguistics, Literature and Culture, 5(6), 102-107. https://doi.org/10.21744/ijllc.v5n6.793 